\title{
A PESQUISA EM SAÚDE/ENFERMAGEM A SERVIÇO DE POPULAÇÕES POBRES E VULNERÁVEIS: PRIORIDADE PARA O MILÊNIO
}

A complexidade do mundo globalizado abre novos desafios e espaços de oportunidade para a epistemologia do conhecimento em Saúde e Enfermagem, voltada para a resolução de problemas sociais que afligem a população mundial, aqui mais particularmente a população brasileira. A pobreza é um destes problemas, que está intimamente relacionado às condições e expectativas de saúde. Caracteriza-se como fenômeno complexo, multidimensional, com privação acentuada dos elementos básicos para uma vida longa e saudável, incluindo falta de alimentação adequada, carência de habitação e vestuário, baixa escolaridade, inserção instável no mercado de trabalho, falta ou pouco acesso a serviços de saúde, a participação social e a decisões políticas, dentre outros aspectos. A pobreza engloba e transcende a deficiência de renda, e abrange concepções como desigualdade, exclusão social e vulnerabilidade. É o resultado do processo histórico, social e econômico, de exclusão social, cultural e política.

A erradicação da pobreza e da fome tornou-se uma das prioridades nas agendas de governos e organizações internacionais, ocupando o primeiro lugar nos Objetivos de Desenvolvimento do Milênio da Organização das Nações Unidas (ONU) para 2015(1). Pobreza e baixos padrões de vida são poderosos determinantes dos problemas de saúde e de desigualdade em saúde ${ }^{(2)}$.

No Brasil, segundo dados da Pesquisa Nacional por Amostra de Domicílio (PNAD), divulgados pelo Instituto Brasileiro de Geografia e Estatística (IBGE), a pobreza e a desigualdade social registraram queda desde 2006 e atingiram níveis mais baixo dos últimos 15 anos $^{(3-4)}$. Embora o Brasil tenha diminuido em seis milhões o número de pessoas que vivem em situação de extrema pobreza, há ainda 36,2 milhões de brasileiros vivendo com até $\mathrm{R} \$ 125,00$ por mês, valor que estabelece a linha de pobreza pela classificação da Fundação Getúlio Vargas. O Brasil ainda se destaca pelas suas assimetrias sociais e processos de exclusão social acentuados. Também ocupa o antepenúltimo lugar na lista dos 191 Estados-Membros, conforme a equidade das contribuições financeiras aos sistemas de saúde ${ }^{(5)}$.

Boa saúde não é simplesmente produto de um aumento econômico, ela depende também da qualidade das políticas de saúde e dos investimentos em saúde ${ }^{(6)}$. Políticas de saúde bem sucedidas são um estímulo para o desenvolvimento econômico e social. Saúde e expectativa de vida são também dependentes da educação, de idéias, técnicas e tecnologias. A construção, socialização e utilização de conhecimento e tecnologia em saúde são tão importante quanto o desenvolvimento econômico. Neste sentido, saúde, ciência e tecnologia têm papel central no desenvolvimento econômico e social, não sendo apenas suas consequências ${ }^{(7,8)}$.

A Conferência Mundial sobre Ciência conclamou governos e cientistas a dar atenção aos complexos problemas da falta de saúde e a crescente desigualdade em saúde através dos diferentes países e entre comunidades do mesmo país, com o objetivo de aprimorar o nível de vida e a qualidade de saúde para todos. A prática da pesquisa científica e o uso do conhecimento produzido deve sempre ter como meta primordial o bem-estar da humanidade, incluindo a redução da pobreza ${ }^{(9)}$.

Cientistas em Saúde e Enfermagem têm uma contribuição fundamental nesta área, a qual engloba um campo vastíssimo de estudos ainda por explorar. Para isto, necessitam priorizar em suas agendas de pesquisa, temas que contribuam para a erradicação da pobreza, a compreensão e a melhoria da saúde e do acesso a serviços de saúde por parte de comunidades, famílias, grupos sociais e pessoas em condição de vulnerabilidade, dentre outros aspectos. No entanto, é preciso destacar que a pesquisa no Brasil tem guardado pouca relação com as necessidades econômicas e sociais ${ }^{(10)}$. Os esforços ainda são tímidos, mas já podemos notar alguns empreendimentos na Enfermagem ${ }^{(11)}$.

Estudos sobre saúde em situações de pobreza são complexos e multidimensionais, o que requer, muitas vezes, abordagens multi, inter e transdisciplinar. Requer, também, diferentes orientações filosóficas e tendências epistemológicas. A diversificação de abordagens metodológicas quanti e qualitativas pode também favorecer estudos em profundidade sobre comunidades, famílias e grupos em situações específicas, sem os quais, políticas adequadas de redução da pobreza se tornam muito difíceis de ser implementadas e avaliadas. Incluir, também, sexo e gênero, bem como outros marcadores sociais (raça, cultura, etnia....) no campo de análise dos dados, pode contribuir para que os resultados de pesquisa se aproximem cada vez mais da realidade investigada. A pesquisa 
necessita ir além do reconhecimento das assimetrias para ser um espaço de reflexão-ação-transformação. Neste sentido, a pesquisa-ação participante vem ganhando espaço internacional, nas mais diferentes áreas do conhecimento, pelo seu caráter político e transformador. Em síntese, a pesquisa em Saúde e Enfermagem necessita estar a serviço das causas sociais e se constituir em instância de transformação social.

\section{REFERÊNCIAS}

1. United Nations. UN Millennium Development Goals (MDG), 2002. Disponível em: http://www.un.org/millenniumgoals/ (11 de Agosto de 2004).

2. Commission on Social Determinants of Health (CSDH). Closing the gap in a generation: health equity through action on the social determinants of health. Final Report of the Commission on Social Determinants of Health. Geneva, World Health Organization, 2008.

3. Instituto Brasileiro de Geografia e Estatística. Pesquisa Nacional por Amostra de Domicílios, 2006. Disponível em: http://www.ibge.gov.br/home/mapa_site/mapa_site.php\#pesquisas (25 de Agosto de 2007).

4. Instituto de Pesquisa Econômica e Aplicada (IPEA). PNAD 2006: Primeiras Análises - Demografia, educação, trabalho, previdência, desigualdade de renda e pobreza. Brasília, Rio de Janeiro, Setembro de 2007. Disponível em: http://www.ipea.gov.br/sites/000/2/pdf_release/18Pnad_Primeiras_Analises_2006.pdf (20 de Setembro de 2008).

5. World Health Organization. The World Health Report 2000. Health Systems: Improving Performance. World Health Organization, Geneva, World Health Reports; 2000.

6. Sen A. Keynote address to the World Health Assembly. Geneva: WHO; 1999.

7. Sachs JD. The essential ingredient. New Scientist. 2002;17:52-5.

8. Sachs JD. Macroeconomics and health: investing in health for economic development. Report of the Commission on Macroeconomics and Health. World Health Organization, Geneva; 2001.

9. World Conference on Science. Declaration on Science and the use of Scientific Knowledge. Paris: UNESCO; 1999.

10. Guimarães R et al. Política Nacional de Ciência, Tecnologia e Inovação em Saúde: uma proposta. Abrasco. Rio de Janeiro; 2002.

11. Marziale MHP, Mendes IAC. Pobreza e desenvolvimento humano: estratégias globais. Rev Latino-Am Enferm. 2007;15(n esp):709-12.

Alcione Leite da Silva

Enfermeira. Pós-doutora em Sociologia da Saúde. Doutora em Filosofia em Enfermagem. Professora Associada da Secção Autônoma de Ciências da Saúde da Universidade de Aveiro. Membro da Unidade de I\&D, Centro de Investigação em Educação e Ciências do Comportamento, Portugal.E-mail: alsilva@ua.pt

Cogitare Enferm 2008 Out/Dez; 13(4):479-83 


\section{HEALTH/NURSING RESEARCH UNDER THE SERVICE OF VULNERABLE POOR POPULATIONS: MILLENNIUM PRIORITY}

The complexity of the globalized world discloses new challenges and opportunities gaps for knowledge epistemology in Health and Nursing aiming at world population's social problem-solving and particularly Brazilian population's. Poverty is one of these problems, which is closely related to health conditions and expectations. It features as a complex, multidimensional phenomenon with sharp deprivation of the basic elements for a long, healthy life, including shortage of proper food, scarcity of housing and clothing, low educational level, unstable insertion in the job market, shortage or scarce access to health services, social participation and political decisions, among other aspects. Poverty entails and transcends income deficiency and takes up conceptions such as inequality, social exclusion and vulnerability. It is the result of a historic, social and economic process of social, cultural and political exclusion.

Eradication of poverty and hunger has become one of the priorities in the agendas of governments and international organizations, ranking the first place in the United Nations Millennium Development Goals (UNO) for 2015. Poverty and low standards of living are powerful determinants for health problems and health inequity.

In Brazil, according to data from the National Survey for Home Sampling (Pesquisa Nacional por Amostragem Domiciliar - PNAD - in Portuguese), released by the Brazilian Institute of Geography and Statistics (Instituto Brasileiro de Geografia e Estatística - IBGE - in Portuguese), poverty and social inequity have been falling since 2006 and have reached the lowest levels for the last 15 years. Although Brazil has decreased its number of six million people living in extreme poverty situation, there are still 36.2 million Brazilians living on up to $\mathrm{R} \$ 125.00$ a month, amount which sets the poverty line according to Getúlio Vargas Foundation (Fundação Getúlio Vargas). Brazil still stands out by its social inequality and sharp processes of social exclusion. It also ranks the second to the last place in the roll of 191 Member-States for equity of financial contributions to health systems.

Good health is not merely a by-product of economic increase; it also relies on the quality of health policies and health investments. Successful health policies foster social and economic development.
Health and life expectation are also dependent on education, ideas, techniques and technologies. The construction, socialization and use of health knowledge and technology are as significant as economic development. Thus, health, science and technology play a central role in the economic and social development; they are not only its consequences.

The World Conference on Science called on governments and scientists to turn their attention to the complex problems of health deprivation as well as to the increasing health inequity throughout different countries and communities in the same country, aiming to improve health and quality level to all. Scientific research practice and use of the produced knowledge must prioritize human kind welfare, poverty reduction inclusive.

Health and Nursing scientists have an utmost contribution in this area which entails a huge studying field to be explored. This means that their research agendas must prioritize themes that contribute to poverty eradication, health understanding and improvement and the access to health services on the part of communities, families, social groups and people in vulnerable condition, among other aspects. However, it must be pointed out that research in Brazil has set scarce connection with economic and social needs. There are still feeble efforts but we can already observe some nursing projects.

Studies on health in poverty contexts are complex and multidimensional which require, in the greatest part, multi, inter and transdisciplinary approaches. They also require different philosophical lines and epistemological trends. The diversification of quanti and qualitative methodological approaches may also favor in-depth studies on communities, families and groups in specific situations which may facilitate the implementation and assessment of adequate policies for poverty reduction. The insertion of sex and gender as social markers (race, culture, etc...) in data analysis may also contribute for research results to get closer and closer to the investigated reality. Research needs to go beyond the recognition of asymmetries in order to be the space for reflectionaction-change. Thus, participating action-research has been gaining international space in the most diversified knowledge areas due to its political and changing character. In short, health and nursing research needs to be under the service of social causes and sets forth as an instance of social change.

\section{REFERÊNCIAS}


1. United Nations. UN Millennium Development Goals (MDG), 2002. Disponível em: http://www.un.org/ millenniumgoals/ (11 de Agosto de 2004).

2. Commission on Social Determinants of Health (CSDH). Closing the gap in a generation: health equity through action on the social determinants of health. Final Report of the Commission on Social Determinants of Health. Geneva, World Health Organization, 2008.

3. Instituto Brasileiro de Geografia e Estatística. Pesquisa Nacional por Amostra de Domicílios, 2006. Disponível em: http://www.ibge.gov.br/home/mapa_site/ mapa_site.php\#pesquisas (25 de Agosto de 2007).

4. Instituto de Pesquisa Econômica e Aplicada (IPEA). PNAD 2006: Primeiras Análises - Demografia, educação, trabalho, previdência, desigualdade de renda e pobreza. Brasília, Rio de Janeiro, Setembro de 2007. Disponível em: http://www.ipea.gov.br/sites/000/2/ pdf_release/18Pnad_Primeiras_Analises_2006.pdf (20 de Setembro de 2008).

5. World Health Organization. The World Health Report 2000. Health Systems: Improving Performance. World Health Organization, Geneva, World Health Reports; 2000.

6. Sen A. Keynote address to the World Health Assembly. Geneva: WHO; 1999.

7. Sachs JD. The essential ingredient. New Scientist. 2002;17:52-5.

8. Sachs JD. Macroeconomics and health: investing in health for economic development. Report of the Commission on Macroeconomics and Health. World Health Organization, Geneva; 2001.

9. World Conference on Science. Declaration on Science and the use of Scientific Knowledge. Paris: UNESCO; 1999.

10. Guimarães R et al. Política Nacional de Ciência, Tecnologia e Inovação em Saúde: uma proposta. Abrasco. Rio de Janeiro; 2002.

11. Marziale MHP, Mendes IAC. Pobreza e desenvolvimento humano: estratégias globais. Rev Latino-Am Enferm. 2007;15(n esp):709-12.

Alcione Leite da Silva Nurse. Post-Doctorate in Health Sociology. PhD in Nursing Philosophy. Associate professor of Health Sciences Autonomous Section at Aveiro University. Member of the I\&D Investigation Center in Education and Behavioral Sciences, Portugal.E-mail: alsilva@ua.pt

\section{LA INVESTIGACIÓN EN SALUD/ ENFERMERÍAASERVICIO DE POBLACIONES POBRESY VULNERABLESS: PRIORIDAD PARAEL MILENIO}

La complejidad del mundo globalizado trae nuevos desafíos y espacios de oportunidad para la epistemología del conocimiento en Salud y Enfermería, que se vuelve a la resolución de problemas sociales los cuales molestan a la población mundial, particularmente la población brasileña. La pobreza es un problema intimamente relacionado a las condiciones y expectativas de salud. Se caracteriza como fenómeno complejo, multidimensional, con privación de los elementos básicos para una vida larga y saludable, lo que abarca falta de alimentación adecuada, carencia de hogar y prendas de vestir, baja escolaridad, inserción inestable en mercado de trabajo, ausencia o poco acceso a servicios de salud, a participación social e a decisiones políticas, entre otros aspectos. La pobreza engloba y trascende la deficiencia de renta, y abarca concepciones, como desigualdad, exclusión social y vulnerabilidad. Es resultado del proceso histórico, social y económico de exclusión social, cultural y política.

La erradicación de la pobreza e de hambre se volvió en una de las prioridades para los governos y organizaciones internacionales, poseyendo el primer lugar en los Objetivos de Desarrollo del Milenio de la Organización de las Naciones Unidas (ONU) para 2015. Pobreza y bajos patrones de vida son grandes determinantes de los problemas de salud y de desigualdad el salud.

En Brasil, de acuerdo con los datos de la Investigación Nacional por Muestra de Domicilio (PNAD), divulgados por Instituto Brasileño de Geografía y Estadística (IBGE), la pobreza y la desigualdad social tienen reducción desde 2006 y alcanzaron niveles más bajos de los últimos 15 años. A pesar de disminuir en seis millones el número de personas que viven en situación de extrema pobreza en Brasil, todavía hay 36,2 millones de brasileños viviendo con hasta $\mathrm{R} \$ 125,00$ por mes, valor que establece la linea de pobreza según la clasificación de Fundação Getúlio Vargas. Brasil aún se destaca por sus asimetrias sociales y procesos de exclusión social acentuados. Además de eso, ocupa el antepenúltimo lugar en la lista de los 191 Estados-Miembros, de acuerdo con la equidad de las contribuciones financieiras a los sistemas de salud.

Buena salud no es simplemente producto de crecimiento económico, depende también de la cualidad 
de las políticas de salud e de los recursos aplicados en salud ${ }^{(6)}$. Políticas de salud de suceso son un estímulo al desarrollo económico y social. Salud y expectativa de vida dependen de educación, de ideas, técnicas y tecnologías. La construcción, la socialización y la utilización del conocimiento y de la tecnología en salud son tan importantes cuanto el desarrollo económico. En ese sentido, salud, ciencia y tecnología tienen papel central en desarrollo económico y social, no siendo sólo sus consecuencias.

La Conferencia Mundial sobre Ciencia ha invitado a governos y a cientistas que pongan atención a los complejos problemas de falta de salud y a la creciente desigualdad por medio de distintos países y entre comunidades del mismo país, con el objetivo de mejorar el nivel de vida, además de la cualidade de salud para todos. La práctica de la investigación científica y el uso del conocimiento producido debe tener siempre como meta el bienestar de la humanidada, incluyendo la reducción de la pobreza.

Cientistas en Salud y Enfermería tienen una contribución fundamental en ese área, la cual engloba un campo vastísimo de estudios todavía por explorar. Así, es necesario priorizar, en las investigaciones, temas que contribuyan con la erradicación de la pobreza, la comprensión y mejoría de la salud y del acceso a servicios de salud por parte de comunidades, familias, grupos sociales y personas en condición de vulnerabilidad, entre otros aspectos. Sin embargo, es necesario destacar que la investigación, en Brasil, tiene poca relación con las necesidades económicas y sociales. Los esfuerzos todavía son tímidos, pero ya podemos percibir que se emprende en Enfermería.

Estudios acerca de salud en situaciones de pobreza son complejos y multidimensionales, lo que requiere, muchas veces, abordajes multi, inter y transdisciplinares. Requiere, también, diferentes orientaciones filosóficas y tendencias epistemológicas. La diversificación de abordajes metodológicos cuantitativos y cualitativos puede, también, favorecer estudios en profundidad sobre comunidades, familias y grupos en situaciones específicas, sin los cuales, se queda dificil implementar y evaluar políticas adecuadas de reducción de pobreza. Añadir, aún, sexo y género, así como otros marcadores sociales (raza, cultura, etnia....) en el campo de análisis de los datos, puede contribuir para que los resultados de investigación se queden cada vez más cerca de la realidad investigada. La investigación necesita ir allá del reconocimiento de las asimetrias a fin de ser un espacio de reflexión-accióntransformación. En ese sentido, la investigación-acción participante tiene ganado espacio internacional en las más distintas áreas de conocimiento, por su carácter político y transformador. En síntesis, la investigación en Salud y Enfermería necesita estar a servicio de las causas sociales y se constituir en instancia de transformación social.

\section{REFERÊNCIAS}

1. United Nations. UN Millennium Development Goals (MDG), 2002. Disponível em: www.un.org/ millenniumgoals.

2. Commission on Social Determinants of Health (CSDH). Closing the gap in a generation: health equity through action on the social determinants of health. Final Report of the Commission on Social Determinants of Health. Geneva, World Health Organization, 2008.

3. IBGE. Pesquisa Nacional por Amostra de Domicílios, 2006. Disponível em: www.ibge.gov.br/home/mapa_site/ mapa_site.php\#pesquisas.

4. Instituto de Pesquisa Econômica e Aplicada (IPEA). PNAD 2006: Primeiras Análises - Demografia, educação, trabalho, previdência, desigualdade de renda e pobreza. Brasília, Rio de Janeiro, Set 2007. Disponível em: www.ipea.gov.br/sites/000/2/pdf_release/ 18Pnad_Primeiras_Analises_2006.pdf.

5. World Health Organization. The World Health Report 2000. Health Systems: Improving Performance. World Health Organization, Geneva, World Health Reports; 2000.

6. Sen A. Keynote address to the World Health Assembly. Geneva: WHO; 1999.

7. Sachs JD. The essential ingredient. New Scientist. 2002;17:52-5.

8. Sachs JD. Macroeconomics and health: investing in health for economic development. Report of the Commission on Macroeconomics and Health. World Health Organization, Geneva; 2001.

9. World Conference on Science. Declaration on Science and the use of Scientific Knowledge. Paris: UNESCO; 1999.

10. Guimarães R et al. Política Nacional de Ciência, Tecnologia e Inovação em Saúde: uma proposta. Abrasco. Rio de Janeiro; 2002.

11. Marziale MHP, Mendes IAC. Pobreza e desenvolvimento humano: estratégias globais. Rev Latino-Am Enferm. 2007;15(n esp):709-12.

Alcione Leite da Silva

Enfermera. Posdoctora en Sociología de la Salud. Doctora en Filosofía de Enfermería. Profesora Asociada de Sección Autónoma de Ciencias de la Salud de Universidade de Aveiro. Miembro de la Unidad de I\&D Centro de Investigación en Educación y Ciencias del Comportamiento, Portugal. E-mail: alsilva@ua.pt 